\title{
Protozoan grazing on planktonic bacteria and its impact on bacterial population
}

\author{
Pirjo Kuuppo-Leinikki
}

Tvärminne Zoological Station, SF-10900 Hanko, Finland

\begin{abstract}
Grazing by heterotrophic nanoflagellates and $<100 \mu \mathrm{m}$ microzooplankton on planktonic bacteria was followed during a mesocosm experiment in the Baltic Sea between 23 July and 12 August 1988 on the SW coast of Finland. During the succession of the planktonic community in one mesocosm, 4 grazing experiments were run with a size-fractionation technique. The size fractions used were: $<1 \mu \mathrm{m}$ (bacterioplankton), $<5 \mu \mathrm{m}$ (bacteria and heterotrophic nanoflagellates), and $<100 \mu \mathrm{m}$ (bacteria, heterotrophic nanoflagellates and ciliates). Clearance rate of $<5 \mu \mathrm{m}$ flagellates was 0.6 to $5.3 \mathrm{nl} \mathrm{flag.}^{-1}$ $\mathrm{h}^{-1}$ Grazing in the $<5 \mu \mathrm{m}$ size fraction was 34 to $134 \%$ of grazing in the $<100 \mu \mathrm{m}$ fraction. The $<5 \mu \mathrm{m}$ and $<100 \mu \mathrm{m}$ protozoa harvested hourly on average 75 and $90 \%$ of bacterial production, respectively. Nonetheless, heterotrophic nanoflagellates could not satisfy their carbon demand trom bacteria. Grazing by protozoa altered bacterial size distribution, and reduced bacterial cell number and production. When the water temperature was ca $20^{\circ} \mathrm{C},<100 \mu \mathrm{m}$ microzooplankton could consume about 50 to $100 \%$ of flagellate standing stock daily. During the $3 \mathrm{wk}$ mesocosm experiment, protozoan clearance rate fluctuated in the $<5$ and $<100 \mu \mathrm{m}$ filtrates by a factor of 9 and 3 , respectively. A fall of water temperature from 18 to $14^{\circ} \mathrm{C}$ was the main factor affecting the activity of the microbial community in the mesocosm.
\end{abstract}

\section{INTRODUCTION}

In the microbial loop (Azam et al. 1983) planktonic bacteria convert dissolved organic substrates to particulate form. Whether the organic carbon is transferred effectively from bacterioplankton to other trophic levels depends on the subsequent steps in the microbial loop.

Heterotrophic nanoflagellates are claimed to be the most important grazers of bacteria and controllers of bacterial populations in both marine (e.g. Fenchel 1982b, Andersen \& Fenchel 1985, McManus \& Fuhrman 1988) and freshwater (Bloem et al. 1989, Sanders et al. 1989) habitats, together with ciliated protozoa (e.g. Fenchel 1980, Gast 1985, Turley et al. 1986, Sherr \& Sherr 1987). Fluctuations of bacterial and flagellate populations show coupled oscillations (Andersen \& Fenchel 1985, Bjørnsen et al. 1988, Wikner \& Hagström 1988), implying close interaction between the 2 groups. The carbon from heterotrophic nanoflagellates is subsequently transported further in the pelagial food web by ciliates and mesozooplankton (Porter et al. 1979, Azam et al. 1983, Rassoulzadegan \& Sheldon 1986). The complexity and effectivity of these processes are still obscure, as are the diverse factors influencing the dynamics of the microbial loop.

In the Baltic Sea heterotrophic flagellates are grazers of autotrophic pico- and nanoflagellates, picoplanktonic cyanobacteria and planktonic bacteria (Kuosa \& Marcussen 1988, Wikner 1989, Kuosa 1990). Kuosa \& Kivi (1989) have emphasized the link between bacteria and heterotrophic nanoflagellates in the carbon flow in the northern Baltic. Little is known however, about the variability of that link, for instance its importance in different nutritional conditions or temperatures. Moreover, the direct influence of flagellate grazing on bacterial populations in the Baltic Sea is largely unknown.

In this study, protozoan grazing was studied during a succession of the planktonic community in an enclosure which was manipulated with nutrient and top predator additions. The following questions were asked: What are the apparent grazing rates of heterotrophic nanoflagellates and ciliates, and how large are their short-term $(<1 \mathrm{wk})$ fluctuations? What part of bacterial grazing is due to small heterotrophic nanoflagellates compared to the rest of the protozoan community? What is the grazing pressure by $<100 \mu \mathrm{m}$ 
protozoa (mainly ciliates) on heterotrophic nanoflagellates? Do heterotrophic nanoflagellates regulate bacterial population by grazing and does flagellate grazing alter the structure of bacterial population?

\section{MATERIAL AND METHODS}

Protozoan grazing experiments were carried out as a joint experiment on plankton dynamics between 23 July and 12 August 1988, in the Tvärminne sea area on the SW coast of Finland, northern Baltic Sea. Pelagial water was enclosed in plastic mesocosms (volume ca $30 \mathrm{~m}^{3}$, diameter $2.15 \mathrm{~m}$, depth $8 \mathrm{~m}$ ). The enclosures were manipulated by sequential additions of inorganic nutrients $\left(\mathrm{PO}_{4}-\mathrm{P}: 4 \mathrm{mg} \mathrm{m}^{-3} \mathrm{~d}^{-1}\right.$ and $\mathrm{NH}_{4}-\mathrm{N}: 16 \mathrm{mg} \mathrm{m}^{-3}$ $\mathrm{d}^{-1}$ ) and young three-spined sticklebacks Gasterosteus aculeatus as predators (90 ind. enclosure $\left.{ }^{-1}\right)$. Each manipulation period lasted for $5 \mathrm{~d}$, and the whole experiment lasted for $21 \mathrm{~d}$. The sequence of manipulations in the enclosure used for protozoan grazing experiments is presented in Fig. 1.

Water temperature was about $20^{\circ} \mathrm{C}$ in the beginning of the enclosure experiment. It dropped drastically several degrees on the 8th experimental day, shortly before grazing Expt III, and remained between 12.5 and $14.5{ }^{\circ} \mathrm{C}$ during the rest of the experiment (Fig. 1). At the beginning of the grazing Expts I, II, III and IV, water temperatures were $21.3,18.0,13.1$ and $14.5^{\circ} \mathrm{C}$, respectively.

The salinity of the water in the enclosure was ca $5 \%$.

Experiments. The protozoan grazing experiments were run using the size-fractionation technique (Wright \& Coffin 1984, Kuuppo-Leinikki \& Kuosa 1990) with $5 \mathrm{~d}$ intervals (Fig. 1). Water samples were taken with a Ruttner-type sampler from $0,1,2,3,4$, and $5 \mathrm{~m}$. An integrated water sample was collected in an autoclaved polycarbonate flask ( 8 1) and transported to the

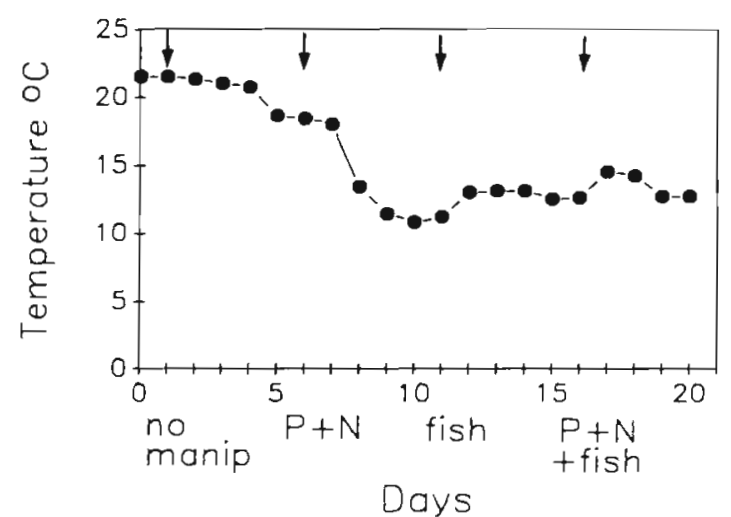

Fig. 1. Water temperature and manipulation periods in the mesocosm experiment, 23 July to 12 August 1988. Arrows: start of grazing experiments laboratory where the water was filtered through a 100 $\mu \mathrm{m}$ plankton net and $5 \mu \mathrm{m}$ and $1 \mu \mathrm{m}$ Nuclepore polycarbonate filters (diam. $50 \mathrm{~mm}$ ) with a sterilized Nalgene filtering device. The $<100$ and $<5 \mu \mathrm{m}$ subsamples were filtered by gravity and $<1 \mu \mathrm{m}$ samples with a vacuum $<2 \mathrm{kPa}$. Expts I and IV were started in the evening and Expts II and III in the morning.

Duplicate $<100,<5$ and $<1 \mu \mathrm{m}$ batch cultures were incubated in a shaker in acid-washed sterile and darkened glass flasks (1 l) in the laboratory for $48 \mathrm{~h}$ and sampled every $12 \mathrm{~h}$. The temperature was adjusted according to the in situ temperature: $18^{\circ} \mathrm{C}$ in Expts I and II, and $10^{\circ} \mathrm{C}$ in III and IV.

Bacterial cell production was measured with the ${ }^{3} \mathrm{H}$ thymidine incorporation technique (Fuhrman \& Azam $1980,1982)$. Duplicate samples and an absorption control killed with formalin (final conc. $0.5 \%$ ) were incubated for $30 \mathrm{~min}$ in identical conditions with fractionated batches using $10 \mathrm{nM}$ methyl- ${ }^{3} \mathrm{H}$-thymidine ( 40 to $42 \mathrm{Ci} \mathrm{mmol}^{-1}$; Radiochemical Centre, Amersham, UK). Incubations were terminated by adding formalin (final conc. $0.5 \%$ ). The samples were extracted in ice-cold TCA, and the particulate material was collected by filtering the sample through a $25 \mathrm{~mm}$ diameter $0.2 \mu \mathrm{m}$ pore size Sartorius membrane filter. The samples were stored at $6^{\circ} \mathrm{C}$ for 3 to $4 \mathrm{~d}$ before the filtration procedure.

The effect of preservation (Bell et al. 1983, Riemann 1985) on ${ }^{3}$ H-thymidine samples was checked. The radioactivity of the samples decreased 7 to $14 \%$ from the original in $4 \mathrm{~d}$. A correction factor to compensate for the decrease was applied in calculations of bacterial cell production.

Conversion factors to estimate bacterial cell production from ${ }^{3} \mathrm{H}$-thymidine incorporation were calculated from the $<1 \mu \mathrm{m}$ size fraction.

Subsamples for cell counts were fixed immediately after sampling with unbuffered glutaraldehyde (final conc. $1 \%$ ). Heterotrophic nanoflagellates and bacteria were stained with proflavine (Haas 1982) and examined with a Leitz Dialux microscope fitted with epifluorescence light with a $100 \times$ oil immersion objective under blue excitation light.

The cell counts were done on the same or the next day after sampling. Flagellates were enumerated from 100 fields, the number of cells counted varying between 30 to 320 . The number of counted bacterial cells was 150 to 450. Flagellates were counted from duplicate filters. Average difference in flagellate counts between the duplicates was 18,19 and $38 \%$ in the $<100,<5$ and $<1 \mu \mathrm{m}$ size fractions, respectively.

The maximum dimension of 100 flagellates from each sample was measured using the New Porton ocular graticule (May 1965). One hundred bacteria were measured with the New Porton graticule. Rod-shaped and coccoid forms were differentiated. 
Total number of microzooplankton was counted from integrated 0 to $5 \mathrm{~m}$ samples taken a day before each grazing experiment. These samples were fixed with Lugol's iodine solution and counted with the Utermöhl technique.

Calculations. Flagellate cell volumes (V) were estimated by the equation of an ellipsoid:

$$
V=\left(\pi l d^{2}\right) / 6
$$

where $\mathrm{l}=$ cell length (diameter of the circle in the grid); $\mathrm{d}=$ cell width (microscopically estimated, on average $2 / 3 \times$ length) .

Bacterial cell volume was estimated by:

$$
V=(\pi / 4) d^{2}(l-d / 3)
$$

where $\mathrm{l}=$ cell length; $\mathrm{d}=$ cell width.

The volumes were converted to carbon units by using the factors $0.22 \mathrm{pgC} \mathrm{m}^{-3}$ for heterotrophic nanoflagellates (Børsheim \& Bratbak 1987) and $0.35 \mathrm{pgC} \mu \mathrm{m}-3$ for bacteria (Bjørnsen 1986).

The generation times (G) of bacteria in the $<1 \mu \mathrm{m}$ size fraction and heterotrophic nanoflagellates in the $<5 \mu \mathrm{m}$ size fraction were calculated by:

$$
\mathrm{G}=\left(\ln 2 /\left(\ln \mathrm{n}_{2}-\ln \mathrm{n}_{1}\right)\right) \mathrm{t}
$$

where $n_{1}=$ cell number at the beginning of the incubation; $\mathrm{n}_{2}=$ cell number at the end of the incubation; $\mathrm{t}=$ duration of the incubation (h).

The conversion factors to estimate bacterial cell production from ${ }^{3} \mathrm{H}$-thymidine incorporation in the $<1 \mu \mathrm{m}$ fraction were calculated according to Riemann et al. (1987):

$$
\mathrm{CF}=\left(\mathrm{n}_{2}-\mathrm{n}_{1}\right) /{ }^{3} \mathrm{H} \text { inc. }
$$

where $n_{1}=$ cell number at the beginning of the incubation; $\mathrm{n}_{2}=$ cell number at the end of the incubation; ${ }^{3} \mathrm{H}$ inc $=$ integrated thymidine incorporation rate during the period.

Grazing rates on bacteria in the $<5$ and $<100 \mu \mathrm{m}$ fractions were calculated from the difference between bacterial cell production measured with the ${ }^{3} \mathrm{H}$-thymidine technique, and the observed number of bacteria (Kuuppo-Leinikki \& Kuosa 1990)

$$
\begin{gathered}
\text { Grazing }=\sum\left(\mathrm{n}_{\text {2est }}-\mathrm{n}_{2 \mathrm{obs}}\right) / \mathrm{s} \\
\mathrm{n}_{\text {2est. }}=\mathrm{n}_{\text {1obs. }}+\mathrm{P}_{1}
\end{gathered}
$$

where $\mathrm{n}_{1}=$ bacterial number at time $\mathrm{t}_{1} ; \mathrm{n}_{2}=$ bacterial number in time $t_{2} ; P_{1}=$ bacterial cell production at time $t_{1}$, using the conversion factor determined in each experiment; $\mathrm{s}=$ number of samplings -1 (applicable only if sampling periods are of the same length).

In both the $<5$ and $<100 \mu \mathrm{m}$ fractions, grazing and clearance rates were expressed as bacteria eaten per flagellate per unit time, because the number of other protozoa in the $<100 \mu \mathrm{m}$ fraction was not known.

Grazing rate by $<100 \mu \mathrm{m}$ protozoa on heterotrophic nanoflagellates was estimated from the difference in flagellate growth between ungrazed $(<5 \mu \mathrm{m})$ and grazed $(<100 \mu \mathrm{m})$ samples:

$$
\text { Grazing }=\text { BB }(5 \mu \mathrm{m})-\mathrm{BB}(100 \mu \mathrm{m})
$$

where $\mathrm{BB}=\mathrm{N}_{\mathrm{o}} \mathrm{e}^{\mathrm{kt}} ; \mathrm{k}=$ flagellate growth constant; $\mathrm{t}=$ time (h).

Statistical analysis. In order to study the impact of grazing on bacterial number and production, linear regression was fitted into the values from the $<1$ and $<5 \mu \mathrm{m}$ size fractions. The regression coefficients between different size fractions were compared statistically. Regressions with an $\mathrm{r}^{2}$ value of $>50 \%$ were analysed further.

\section{RESULTS}

\section{Bacterial number}

Virtually all the planktonic bacteria were unattached in the experiments, and the effect of filtration on bacterial number was negligible. The differences in bacterial densities between $<100,<5,<1 \mu \mathrm{m}$ and filtrates were always within the error of microscopical counts.

Generation times of the bacterial population in the $<1 \mu \mathrm{m}$ fraction were 3 to $5 \mathrm{~d}$ (Table 1 ).

The number of bacteria after filtration was 3.5 to 7.5 $\times 10^{6}$ cells $\mathrm{ml}^{-1}$, and it varied during the $48 \mathrm{~h}$ incubation from 2.8 to $10.9 \times 10^{6}$ cells ml $^{-1}$ (Fig. 2). Bacterial numbers increased in the $<1 \mu \mathrm{m}$ size fraction, but in the presence of protozoan grazers they remained more or less constant (Expts III and IV) or decreased (I and II). The control of bacterial abundance by heterotrophic nanoflagellates in the $<5 \mu \mathrm{m}$ size fraction in Expt II was statistically significant (Table 2).

\section{Bacterial production}

The average conversion factor for bacterial cell production, calculated from the $<1 \mu \mathrm{m}$ size fraction, was $0.1 \times 10^{9}$ cells nmol $^{-1}$ (range 0.7 to $1.4 \times 10^{9}$ ).

At the beginning of each experiment, bacterial cell production was comparable in all size fractions (Fig. 3). In the $<1 \mu \mathrm{m}$ size fractions bacterial production increased, reaching values of 4.3 to $7.9 \times 10^{4}$ cells ml $^{-1}$ $\mathrm{h}^{-1}$ (Fig. 3C). In the $<5$ and $<100 \mu \mathrm{m}$ size fractions there was a decline in cell production in Expts II and IV but an increase in Expts I and III, which in Expt I exceeded the $<1 \mu \mathrm{m}$ size fraction (Fig. 3).

Protozoan grazing in the $<5 \mu \mathrm{m}$ size fraction significantly reduced bacterial production in Expts II and III (Table 2). 
Table 1. Bacterial and protozoan parameters at the beginning of grazing incubations during the mesocosm experiment between 23 July and 12 August 1988. All values are from the $<100 \mu \mathrm{m}$ size fraction unless otherwise mentioned

\begin{tabular}{|c|c|c|c|c|}
\hline Parameter & Expt I & Expt II & Expt III & Expt IV \\
\hline Bacterial density (cells $\mathrm{ml}^{-1}$ ) & $6.5 \times 10^{6}$ & $6.8 \times 10^{6}$ & $3.9 \times 10^{6}$ & $6.4 \times 10^{6}$ \\
\hline Average volume of bacteria $\left(\mu \mathrm{m}^{3}\right)^{\mathrm{d}}$ & 0.049 & 0.043 & 0.032 & 0.038 \\
\hline Bacterial production (cells $\mathrm{ml}^{-1} \mathrm{~h}^{-1}$ ) & $3.7 \times 10^{4}$ & $6.6 \times 10^{4}$ & $1.3 \times 10^{4}$ & $8.0 \times 10^{4}$ \\
\hline HNAN density (cells $\mathrm{ml}^{-1}$ ) & $2.4 \times 10^{3}$ & $2.1 \times 10^{3}$ & $4.8 \times 10^{3}$ & $1.8 \times 10^{3}$ \\
\hline Average volume of HNAN $\left(\mathrm{um}^{3}\right)$ & 25.9 & 17.0 & 23.6 & 39.2 \\
\hline Microzooplankton density, total (cells $\left.l^{-1}\right)^{b}$ & $1.9 \times 10^{4}$ & $2.5 \times 10^{4}$ & $8.1 \times 10^{3}$ & $2.0 \times 10^{4}$ \\
\hline Generation time of bacteria $(\mathrm{d})^{\mathrm{c}}$ & 5 & 3 & 5 & 3 \\
\hline Generation time of HNAN (d) $)^{a, c}$ & 1. & 0.7 & 8 & 21 \\
\hline \multicolumn{5}{|l|}{${ }^{a}$ Value from the $<5 \mu \mathrm{m}$ size fraction } \\
\hline \multicolumn{5}{|l|}{ b Value from the enclosure } \\
\hline c Value from 48 h incubation & & & & \\
\hline
\end{tabular}

Table 2. Effect of flagellate grazing on bacterial density and production: regression coefficients of bacterial cell number and production against time in $<1$ and $<5 \mu \mathrm{m}$ filtrates were compared statistically. "Regressions with $r^{2}<50 \%$; were not analyzed

\begin{tabular}{|c|c|c|}
\hline & $\begin{array}{l}\text { Regression } \\
\text { of bacterial } \\
\text { cell number }\end{array}$ & $\begin{array}{l}\text { icient }(\mathrm{r} \text { ) } \\
\text { of bacterial } \\
\text { production }\end{array}$ \\
\hline \multicolumn{3}{|l|}{ Expt I } \\
\hline$<1 \mu \mathrm{m}$ & $4.0 \times 10^{4}$ & $2.0 \times 10^{2}$ \\
\hline$<5 \mu \mathrm{m}$ & $-3.9 \times 10^{3}$ & $3.4 \times 10^{2}$ \\
\hline Significance & not tested & not tested \\
\hline \multicolumn{3}{|l|}{ Expt II } \\
\hline$<1 \mu \mathrm{m}$ & $8.0 \times 10^{4}$ & $3.0 \times 10^{2}$ \\
\hline$<5 \mu \mathrm{m}$ & $-5.3 \times 10^{4}$ & $-5.0 \times 10^{2}$ \\
\hline Significance & $\mathrm{p}<0.001$ & $p<0.001$ \\
\hline \multicolumn{3}{|l|}{ Expt III } \\
\hline$<1 \mu \mathrm{m}$ & $3.6 \times 10^{4}$ & $1.0 \times 10^{3}$ \\
\hline$<5 \mu \mathrm{m}$ & $1.3 \times 10^{4}$. & $4.9 \times 10^{2}$ \\
\hline Significance & not tested & $p<0.001$ \\
\hline \multicolumn{3}{|l|}{ Expt IV } \\
\hline$<1 \mu \mathrm{m}$ & $8.3 \times 10^{4}$ & $2.6 \times 10^{2}$ \\
\hline$<5 \mu \mathrm{m}$ & $7.4 \times 10^{3}$ & $-6.8 \times 10^{2}$ \\
\hline Significance & not tested & not tested \\
\hline
\end{tabular}

\section{Bacterial size dístribution}

At the beginning of the incubations, average volume of bacteria was $0.041 \mu^{3}$ (Table 1). The bacteria were largest in the first 2 experiments. Bacterial size difference was statistically insignificant between the experiments, as well as before and immediately after the filtration through the $1 \mu \mathrm{m}$ filter.

The percentage of cells $<0.05 \mu \mathrm{m}^{3}$ was 80 to $91 \%$ in the beginning of the experiments, and it decreased to 65 to $76 \%$ during the incubation in the $<1 \mu \mathrm{m}$ fraction. In the grazed samples $(<5 \mu \mathrm{m})$ the proportion of the smallest cells remained 83 to $86 \%$, but decreased in Expt III to $62 \%$.
Average bacterial volume in the $<1 \mu \mathrm{m}$ size fraction increased during the $48 \mathrm{~h}$ incubation, but significantly only in Expts II and III (Table 3). In the presence of heterotrophic nanoflagellates $(<5 \mu \mathrm{m})$ the mean cell size decreased in the first 2 experiments, but increased in Expt III (Table 3).

The proportion of rods increased during incubations in the $<1 \mu \mathrm{m}$ size fraction, but decreased in the $<5 \mu \mathrm{m}$ fraction (Fig. 4). The elongation of the cells was most pronounced in Expt III, coinciding with low bacterial number and intensive cell production, probably caused by weak grazing pressure. In contrast, the proportion of rods in the $<1 \mu \mathrm{m}$ fraction decreased in Expt II, when the grazing rate of protozoa was highest.

\section{Number of heterotrophic nanoflagellates}

The taxonomical composition of the community of heterotrophic flagellates in the enclosure was studied (Vors unpubl.). About 40 taxa of heterotrophic nanoflagellates were detected in the enclosure.

Immediately after the filtration, the number of heterotrophic nanoflagellates varied between $0.9 \times 10^{2}$ and $4.8 \times 10^{3}$ cells $\mathrm{ml}^{-1}$. In the $<5 \mu \mathrm{m}$ fraction the flagellate number was 55 to $100 \%$, and in the $<1 \mu \mathrm{m}$ fraction 9 to $28 \%$ of that in the $<100 \mu \mathrm{m}$ fraction (Fig. 5).

During the incubation, the flagellate number remained constant in the $<1 \mu \mathrm{m}$ size fraction (Fig. 5C). It was 2.4 to $11.0 \%$ of the number in the $<100 \mu \mathrm{m}$ size fraction. Without grazers ( $<5 \mu \mathrm{m}$ size fraction) flagellate density increased 5 - and 10 -fold in the first 2 experiments, but remained more or less constant in Expts III and IV (Fig. 5B). In the $<100 \mu \mathrm{m}$ filtrate, flagellate growth was slower than in the $<5 \mu \mathrm{m}$ filtrate in Expts I and II, which was attributed to microzooplankton grazing. In the last 2 experiments the growth was equal in the $<5$ um and $<100$ um fractions (Fig. 5A), 


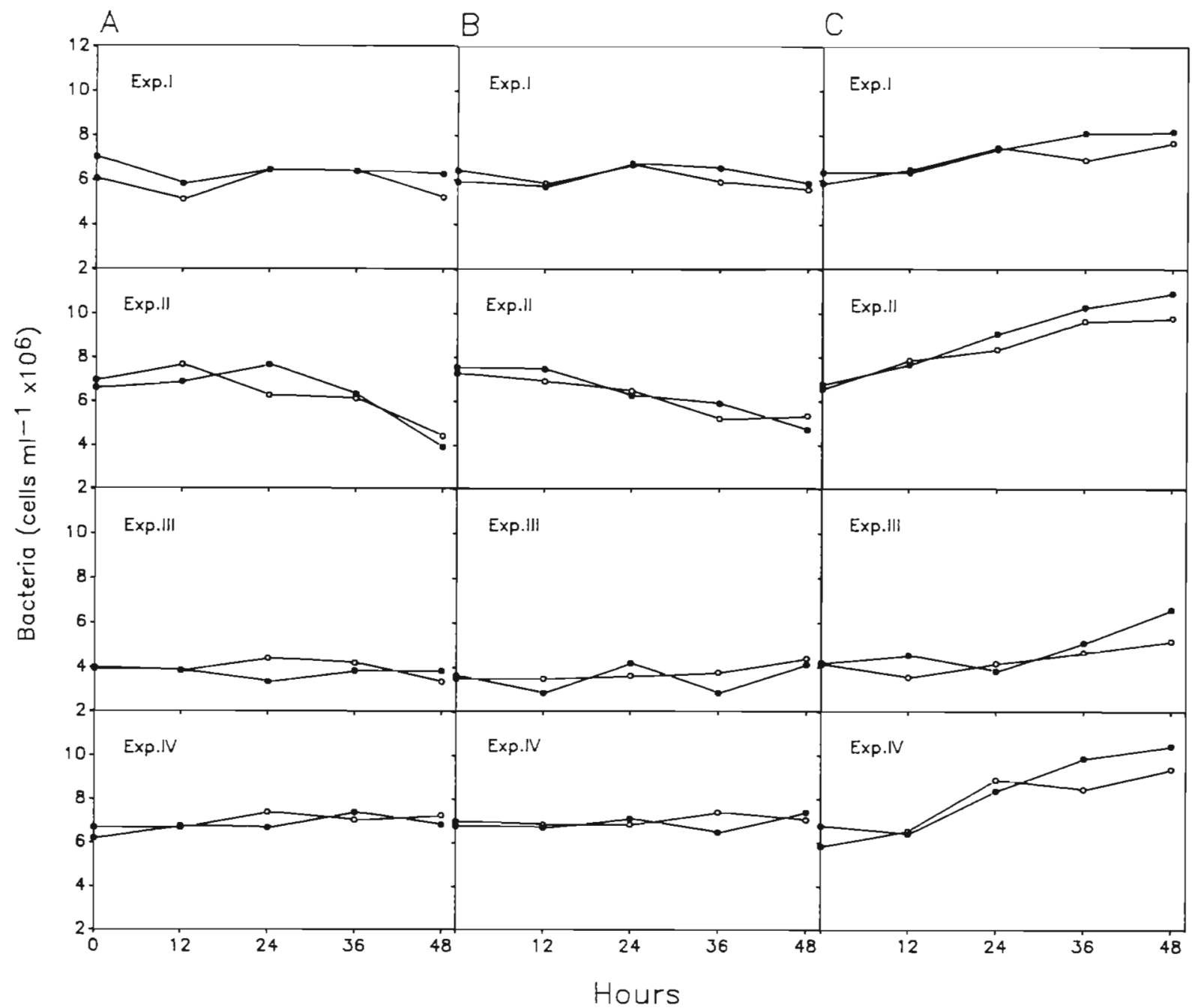

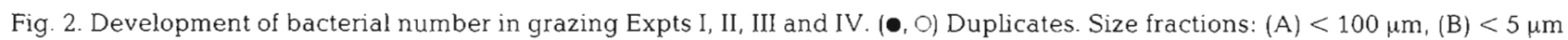
and $(\mathrm{C})<1 \mu \mathrm{m}$

Generation time of heterotrophic nanoflagellates varied between 0.7 and $21 \mathrm{~d}$ (Table 1). It seemed to be affected by the incubation temperature.

\section{Size distribution of heterotrophic nanoflagellates}

The mean volume of heterotrophic nanoflagellates at the beginning of the grazing experiments varied between 17.0 and $39.2 \mu \mathrm{m}^{3}$ (Table 1). The average flagellate volume decreased during the incubations, except in the $<100 \mu \mathrm{m}$ filtrate in the first experiment.

In the $<100 \mu \mathrm{m}$ size fraction, flagellate size distribution varied significantly between the experiments (1way ANOVA: $p<0.001$, Tukey's a posteriori test: all experiments different), but filtration through $5 \mu \mathrm{m}$ equalized the cell size distribution between the experiments (1-way ANOVA: p<0.001, Tukey's a posteriori test: only Expt I different), as the largest flagellates were retained on the $<5 \mu \mathrm{m}$ filter. Taking the whole set of flagellate cell sizes during the incubation, the difference between the $<100$ and $<5 \mu \mathrm{m}$ size fractions remained statistically significant in all experiments except Expt I (Table 4).

\section{Microprotozoa}

The total cell numbers of $<100 \mu$ microzooplankton (ciliates) in the enclosure, on the day before grazing

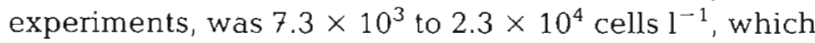
is fairly high compared to the results of Kivi (1986).

The microzooplankton that passes the $<100 \mu \mathrm{m}$ net consists mainly of ciliates (K. Kivi unpubl.), of which Lohmanniella oviformis, Strombidium sp. and Urotrichia sp. were dominant. Nano-sized $(<20 \mu \mathrm{m})$ unidentified ciliates were found before Expts I, II and IV in densities between 3.0 and $1.9 \times 10^{2}$ cells $1^{-1}$. 


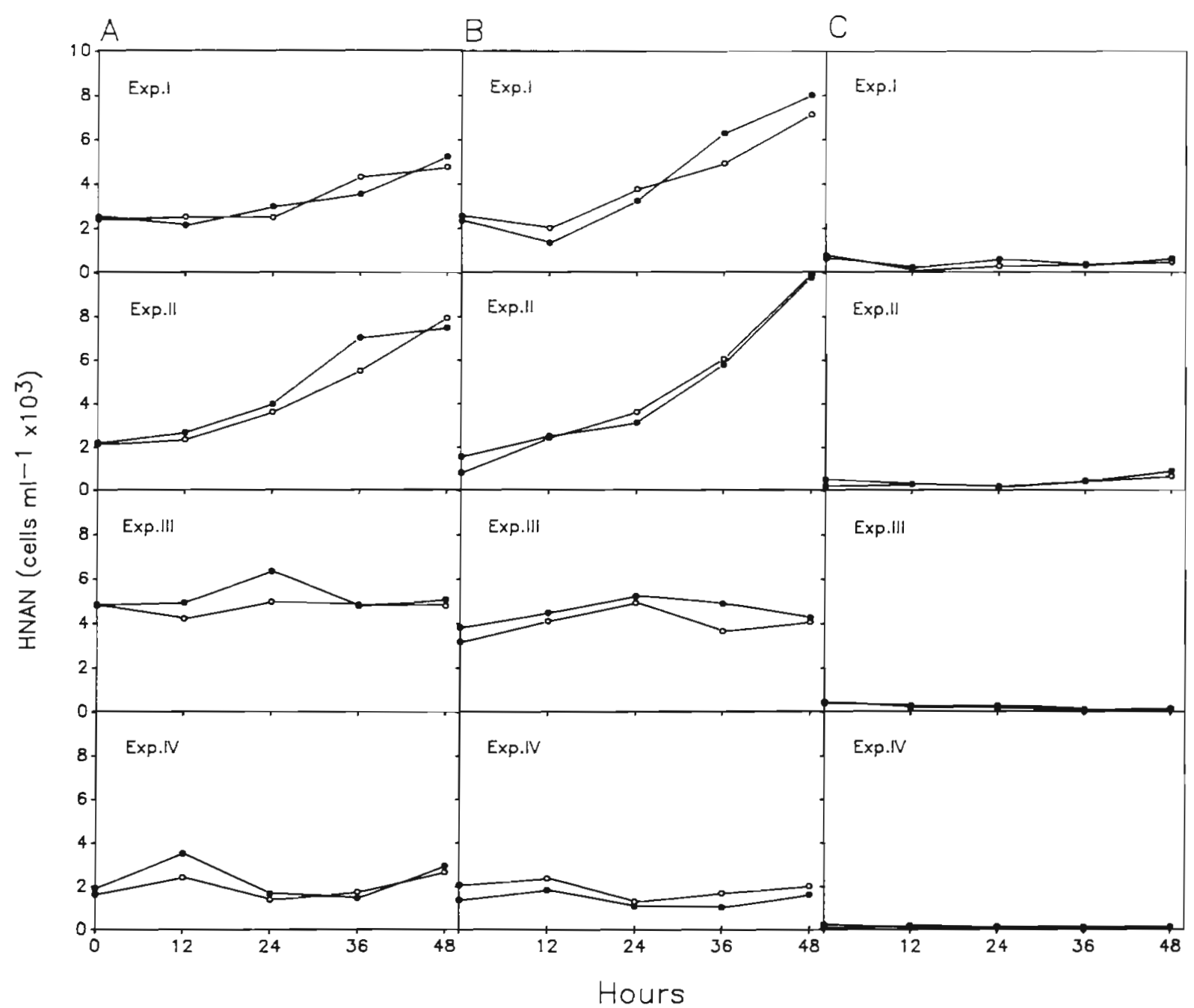

Fig. 3. Bacterial cell production in grazing Expts I to IV $(\bullet$, o) Duplicates. Size fractions: $(\mathrm{A})<100 \mu \mathrm{m},(\mathrm{B})<5 \mu \mathrm{m}$ and $(\mathrm{C})<1 \mu \mathrm{m}$

Table 3. Effect of flagellate grazing on bacterial cell volume, tested with Mann-Whitney's U-test

\begin{tabular}{|c|c|c|c|}
\hline & \multicolumn{2}{|c|}{ Mean cell volume $(\mathrm{SD})\left(\mu \mathrm{m}^{3}\right)$} & \multirow[t]{2}{*}{ Significance } \\
\hline & & & \\
\hline \multicolumn{4}{|l|}{ Expt I } \\
\hline$<1 \mu \mathrm{m}$ & $0.024(0.027)$ & $0.086(0.418)$ & $p=0.0811$ \\
\hline$<5 \mu \mathrm{m}$ & $0.049\{0.124\}$ & $0.042(0.091)$ & $\mathrm{p}=0.9047$ \\
\hline \multicolumn{4}{|l|}{ Expt II } \\
\hline$<1 \mu \mathrm{m}$ & $0.028(0.050)$ & $0.057(0.086)$ & $\mathrm{p}=0.0045$ \\
\hline$<5 \mu \mathrm{m}$ & $0.043(0.089)$ & $0.030(0.057)$ & $p=0.1498$ \\
\hline \multicolumn{4}{|l|}{ Expt III } \\
\hline$<1 \mu \mathrm{m}$ & $0.024(0.052)$ & $0.084(0.139)$ & $\mathrm{p}=0.0000$ \\
\hline$<5 \mu \mathrm{m}$ & $0.032(0.080)$ & $0.095(0.174)$ & $p=0.0151$ \\
\hline \multicolumn{4}{|l|}{ Expt IV } \\
\hline$<1 \mu \mathrm{m}$ & $0.031(0.048)$ & $0.049(0.081)$ & $p=0.0693$ \\
\hline$<5 \mu \mathrm{m}$ & $0.038(0.061)$ & $0.034(0.065)$ & $p=0.0661$ \\
\hline
\end{tabular}

\section{Grazing by protozoa}

The ingestion rate varied from 2.0 to 36.8 bacteria flagellate ${ }^{-1} \mathrm{~h}^{-1}$ and clearance rate from 0.6 to $5.3 \mathrm{nl}$

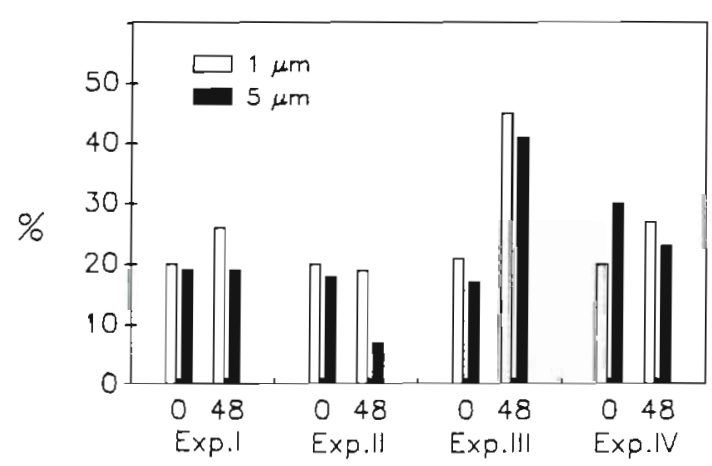

Fig. 4. Proportion of rod-shaped bacteria at the beginning (0) and at the end (48) of the grazing experiments

flagellate ${ }^{-1} \mathrm{~h}^{-1}$ (Table 5 ). The ingestion and clearance values in the $<5 \mu \mathrm{m}$ filtrate were from 34 to 134 ... of that in the $<100 \mu \mathrm{m}$ filtrate. In Expt IV, grazing was more intensive in the fraction with only small flagellates than in the fraction with large flagellates and other protozoa. After the temperature drop (Expt III), the contribution of $<5 \mu \mathrm{m}$ flagellates to grazing was 


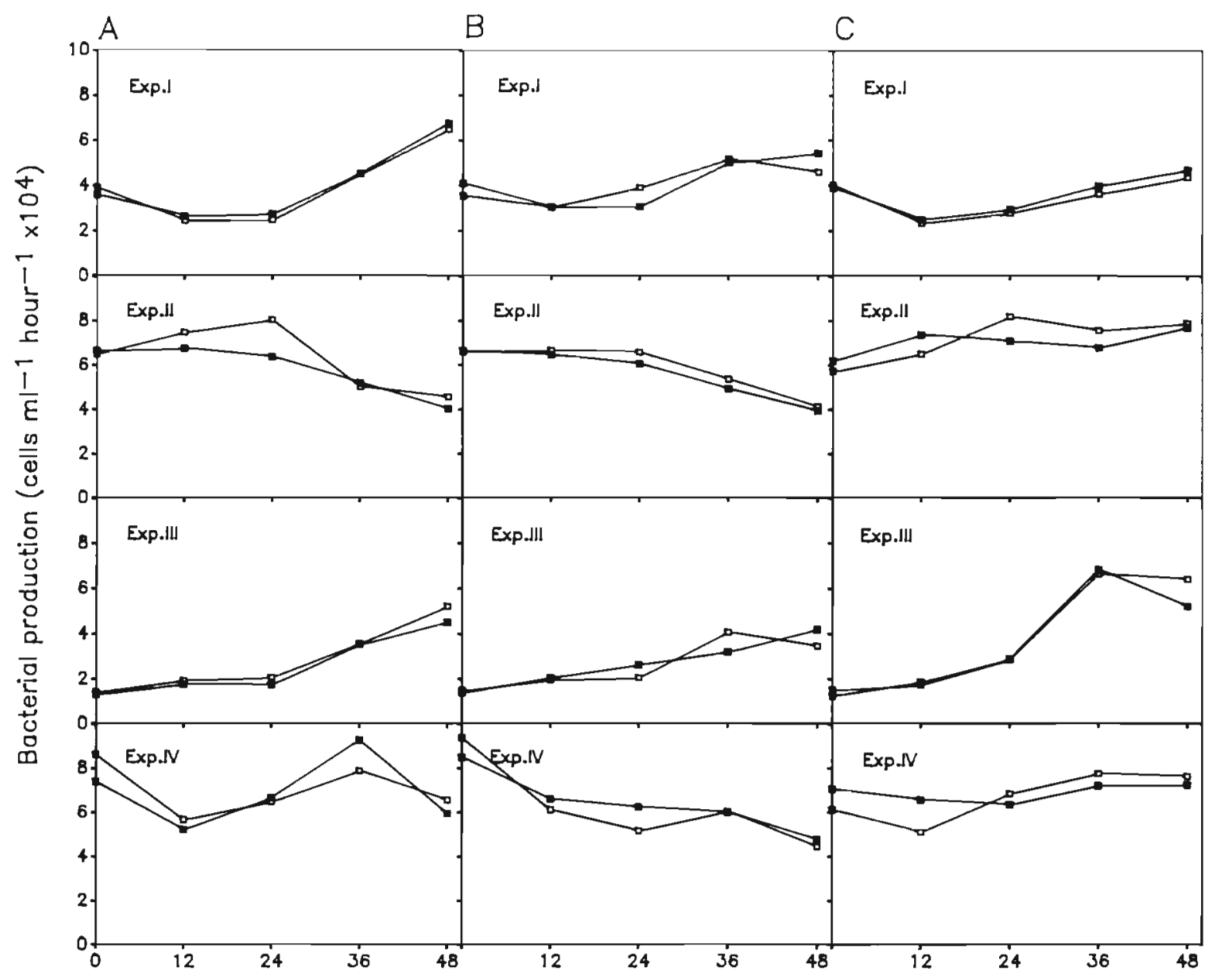

Hours

Fig. 5. Number of heterotrophic nanoflagellates in the grazing experiments. (B) $<5 \mu \mathrm{m}$ and $(\mathrm{C})<1 \mu \mathrm{m}$

smallest. Volume-specific clearance in the $<5 \mu \mathrm{m}$ size fraction was 0.4 to $2.9 \times 10^{5} \mathrm{~h}^{-1}$ (Table 5). Clearance rate of bacteria by the protozoan community varied from 1.0 to $6.6 \times 10^{4}$ bacteria $\mathrm{ml}^{-1} \mathrm{~h}^{-1}$, which corresponded to between 5 and $23 \%$ of the water column per day. The protozoa cleared on average $83 \%$ of bacterial cell production (Table 5).

Bacterial carbon consumption per flagellate biomass varied from 1 to $12 \% \mathrm{~h}^{-1}$ (Table 5). The value was largest when grazing rates were high.

Apparent gross growth efficiency of heterotrophic nanoflagellates was from 0.6 to $105 \%$ (Table 5). Lowest values were obtained when grazing rate, bacterial number and cell production were low and bacteria were small (Table 5).

The drop in water temperature from 18 to $13^{\circ} \mathrm{C}$ between Expts II and III was accompanied by decreased bacterial density, biomass and production (Table 1), increased protozoan density, biomass and flagellate generation time and decreased protozoan grazing efficiency (Tables 1 and 5). In Expt IV the microbial community probably had changed, and consisted of species that were adapted to lower temperature.

\section{DISCUSSION}

\section{Bacterial numbers and production}

The number and biovolume of bacteria were in accordance with previous studies from the Tvärminne area (e.g. Väätänen 1981, Virtanen 1985, Kuparinen 1987). The high proportion of small cocci in the Baltic Sea especially in summer has also been reported by Virtanen (1985) and Andersson et al. (1986). It has been suggested as a consequence of size selective grazing by nanoflagellates (Andersson et al. 1986).

The small cell size may also refer to the dormant state of the bacteria (e.g. Bell et al. 1983), which can also cause the long doubling time of the population (Moriarty \& Pollard 1982, Riemann et al. 1984). As the 
enclosure experiment started during a period of outflow of less saline water from an inner archipelago, a high proportion of dormant bacteria is possible. Yet, the generation times of the bacterial population in this study ( 3 to 5 d) were not exceptionally long (Fuhrman \& Azam 1982, Riemann et al. 1984, Moriarty et al. 1985).

In the grazing experiments practically all the bacteria were free-living. Moreover, Väätänen (1981) observed that a maximum of 4 to $6 \%$ of bacteria were attached to planktonic algae and detritus particles in the Tvärminne area during summer. This fact decreases the risk of obtaining underestimated grazing values with the fractionation method, caused by retention of particles on the $5 \mu \mathrm{m}$ filter, and so excluding any particle-associated flagellates (Fenchel 1982b, Caron 1987. Sibbald \& Albright 1988).

Table 4. Difference in size distribution of heterotrophic nanoflagellates between $<5$ and $<1.00$ um filtrates, tested with Student's t-test

\begin{tabular}{|llll|}
\hline & $\begin{array}{c}\text { Mean diameter of HNAN } \\
(\text { SD) }(\mu \mathrm{m})\end{array}$ & Significance \\
& $<100 \mu \mathrm{m}$ & $<5 \mu \mathrm{m}$ & \\
\hline Expt I & $4.219(1.483)$ & $4.144(1.449)$ & $\mathrm{p}=0.3018$ \\
Expt II & $3.966(1.223)$ & $3.870(1.130)$ & $\mathrm{p}=0.0396$ \\
Expt III & $4.513(1.400)$ & $4.228(1.208)$ & $\mathrm{p}=0.0005$ \\
Expt IV & $4.897(1.673)$ & $4.346(1.305)$ & $\mathrm{p}=0.0000$ \\
\hline
\end{tabular}

The conversion factors for bacterial cell production obtained in this study $\left(0.7\right.$ to $1.4 \times 10^{9}$ cells $\left.\mathrm{nmol}^{-1}\right)$ were in the lower end of the spectrum reported in the literature (Kirchman et al. 1982, Riemann et al. 1987. Coveney \& Wetzel 1988, Smits \& Riemann 1988). However, they were in accordance with the theoretical value (Fuhrman \& Azam 1980) and values previously obtained in the Tvärminne area (Kuparinen 1987). Therefore, the factors of this study were used instead of literature values for calculations of bacterial production.

\section{Heterotrophic nanoflagellates in the filtrates}

The number and size of heterotrophic nanoflagellates were in the same range as values from the study of Kuosa \& Marcussen (1988) and Kuuppo-Leinikki \& Kuosa (1990) from the Tvärminne area. The proportion of heterotrophic nanoflagellates that passed the 5 and $1 \mu \mathrm{m}$ filters is in agreement with the results of Wikner \& Hagström (1988). In their study, however, filtration reduced bacterial counts, which did not occur in these experiments.

The number of heterotrophic nanoflagellates in the $<1 \mu \mathrm{m}$ filtrate did not increase during the incubation, which implies that the flagellates either were damaged after being squeezed through 1 um pores, or were

Table 5. Results from the protozoan grazing incubations during mesocosm experiment between 23 July and 12 August 1988 . All values are from $48 \mathrm{~h}$ incubations

\begin{tabular}{|c|c|c|c|c|}
\hline & Expt I & Expt II & Expt III & Expt IV \\
\hline \multicolumn{5}{|l|}{ Ingestion rate (bact flag. ${ }^{-1} \mathrm{~h}^{-1}$ ) } \\
\hline$<5 \mu \mathrm{m}$ & 11.6 & 24.4 & 2.0 & 36.8 \\
\hline$<100 \mu \mathrm{m}$ & 15.3 & 26.7 & 5.8 & 27.6 \\
\hline$\%(<5 \mu \mathrm{m} /<100 \mu \mathrm{m})$ & 75 & 91 & 34 & 134 \\
\hline \multicolumn{5}{|l|}{ Clearance rate (nl flag ${ }^{-1} \mathrm{~h}^{-1}$ ) } \\
\hline$<5 \mu \mathrm{m}$ & 1.9 & 3.9 & 0.6 & 5.3 \\
\hline$<100 \mu \mathrm{m}$ & 2.5 & 4.2 & 1.5 & 4.0 \\
\hline \multicolumn{5}{|l|}{ Volume-specific clearance (flag. $\mathrm{h}^{-1}$ ) } \\
\hline$<5 \mu \mathrm{m}$ & $1.1 \times 10^{5}$ & $2.8 \times 10^{5}$ & $0.4 \times 10^{5}$ & $2.8 \times 10^{5}$ \\
\hline$<100 \mu \mathrm{m}$ & $1.3 \times 10^{5}$ & $2.9 \times 10^{5}$ & $0.7 \times 10^{5}$ & $1.4 \times 10^{5}$ \\
\hline \multicolumn{5}{|l|}{ Predation rate (bact. $\mathrm{ml}^{-1} \mathrm{~h}^{-1}$ ) } \\
\hline$<5 \mu \mathrm{m}$ & $2.8 \times 10^{4}$ & $5.1 \times 10^{4}$ & $1.0 \times 10^{4}$ & $6.6 \times 10^{4}$ \\
\hline$<100 \mu \mathrm{m}$ & $3.7 \times 10^{4}$ & $5.6 \times 10^{4}$ & $2.8 \times 10^{4}$ & $5.0 \times 10^{4}$ \\
\hline \multicolumn{5}{|l|}{ Predation/production } \\
\hline$<5 \mu \mathrm{m}$ & $68 \%$ & $89 \%$ & $38 \%$ & $105 \%$ \\
\hline$<100 \mu \mathrm{m}$ & $93 \%$ & $93 \%$ & $104 \%$ & $71 \%$ \\
\hline $\begin{array}{l}\text { Carbon consumption per flagellate biomass } \\
\text { (in } 1 \mathrm{~h} \text { ) }\end{array}$ & $5 \%$ & $11 \%$ & $1 \%$ & $12 \%$ \\
\hline Gross growth efficiency of HNAN ${ }^{a}$ & $105 \%$ & $39 \%$ & $0.6 \%$ & $3 \%$ \\
\hline $\begin{array}{l}\text { Microzooplankton ingestion rate of HNAN } \\
\text { (flag protoz }{ }^{-1} \mathrm{~h}^{-1} \text { ) }\end{array}$ & 2.5 & 4.7 & 0 & 0 \\
\hline "Value calculated only from $<5 \mu \mathrm{m}$ size fra & & & & \\
\hline
\end{tabular}


dormant stages that might start dividing after $48 \mathrm{~h}$ (Kuuppo-Leinikki \& Kuosa 1990). Multiplying the ingestion rate in the $<5 \mu \mathrm{m}$ fraction by the flagellate number in the $<1$ um fraction, the estimated loss of bacteria via flagellate grazing throughout the experiments was maximally between 1 and $15 \%$ of the production of new bacterial cells. Therefore, the effect of heterotrophic nanoflagellates on bacteria, e.g. the conversion factor for bacterial production in the $<1 \mu \mathrm{m}$ filtrate (Fuhrman \& McManus 1984, Cynar et al. 1985), was minor. The study of Wikner \& Hagström (1988) from the Baltic Sea also showed that the flagellate predation rate decreases sharply in $<1 \mu \mathrm{m}$ water sample. Lysis of bacterial cells by viruses (Bergh et al. 1989) could have caused loss of bacteria in the $<1 \mu \mathrm{m}$ filtrate, which probably lowered the conversion factor. However, it is reasonable to assume that the rate of viral infection was equal in $<1,<5$ and $<100 \mu \mathrm{m}$ filtrates, and it had no effect on the apparent grazing rates.

\section{Grazing on bacteria by heterotrophic flagellates}

Ingestion and clearance rates of heterotrophic nanoflagellates were low compared to values obtained with labeled bacteria as food tracers for natural assemblages (e.g. Sherr et al. 1986, Wikner et al. 1986, Wikner \& Hagström 1988, Wikner et al. unpubl.). They were, however, in accordance with several other studies done with natural water samples (Wright \& Coffin 1984 Coffin \& Sharp 1987, Bjornsen et al. 1988, Kuosa \& Marcussen 1988, Kuuppo-Leinikki \& Kuosa 1990). The fractionation method tends to give somewhat lower grazing values than the use of labeled bacteria.

The volume-specific clearances laverage $1.8 \times 10^{5}$ $\mathrm{h}^{-1}$ ) were in accordance with the values of e.g. Fenchel (1982a), McManus \& Fuhrman (1988) and Nygaard et al. (1988), which implies that the low grazing values of these experiments could be due to the small size of flagellates.

In the experiments the $<5 \mu \mathrm{m}$ flagellates were able to graze, on average, $75 \%$, and the $<100 \mu \mathrm{m}$ protozoa $90 \%$ of bacterial production, which agrees with the level reported in the literature (Wikner et al. 1986 , McManus \& Fuhrman 1988, Roman et al. 1988, Wikner et al. unpubl.). It seems that also in the Baltic Sea protozooplankton, especially heterotrophic nanoflagellates < $5 \mu \mathrm{m}$ (Wright \& Coffin 1984, Wikner \& Hagström 1988, Wikner et al, unpubl.), are mainly responsible for bacterial grazing.

In the northern Baltic Sea the effective harvesting of the bacterial population cannot satisfy the carbon demand of heterotrophic nanoflagellates (Kuosa \& Kivi 1989). In this study, the flagellates $<5$ um derived only 1 to $12 \%$ hourly of their carbon biomass from bacteria.
Most probably the heterotrophic flagellates used carbon sources other than bacteria: pico- and nanoplanktonic eucaryotes (Parslow et al. 1986, Kuosa \& Marcussen 1988) and picoplanktonic cyanobacteria (Campbell \& Carpenter 1986, Kuosa 1990) or possibly high molecular weight DOC (Sherr 1988).

Apparent flagellate growth yield (gross growth efficiency 0.6 to $105 \%$ ) varied widely in these experiments. The values were calculated on the basis of bacterial carbon only. The value exceeding $100 \%$ also implied that flagellates used other carbon sources in addition to bacterioplankton. When water temperature was low, growth efficiency was low and heterotrophic flagellates likely used the carbon only for maintenance. According to Caron et al. (1986), low water temperature does not affect flagellate gross growth efficiency. The result of this study, however, was a property of the whole flagellate community, in which the growth efficiency of a single species was not necessarily changed. on the other hand, volume estimates and carbon conversion factors used for bacteria and their grazers may severely influence the growth yield estimates (Bratbak 1987).

\section{Effect of grazing on bacterial population}

Heterotrophic nanoflagellates not only grazed most of the bacterial production, but the predators also reduced bacterial cell production. However, the increased concentration of substrates and nutrients released by filtration. (Fuhrman \& Bell 1985) in the $<1$ $\mu m$ filtrate probably masked the effect of reduced nutrient regeneration (Sherr et al. 1983, Goldman et al. 1985, Andersen et al. 1986) and substrate release (Andersson et al. 1985, Turley et al. 1986) by protozoa, which normally enhances bacterial production.

Heterotrophic nanoflagellates showed apparent size selectivity towards larger rod-shaped bacteria, a feature that has been observed among protozoa (Andersson et al. 1986, Turley et al. 1986, Krambeck 1988). The cell volume of bacteria in the ungrazed fraction increased significantly, whereas flagellate grazing kept the cell volume small. Also the change in the proportion of rods showed the effect of predation. In all experiments, the percentage of rods in the fraction with predators remained constant as opposed to the fraction without predators. When predation pressure was weak due to low temperature, the number of rods, as well as large cells in general, increased considerably. The increase was not as pronounced in grazed as in ungrazed fractions. It is possible that small cells, which dominated the bacterial community, were below the threshold size for the flagellates (Andersson et al. 1986). 


\section{Effects of temperature}

Water temperature had a major effect on the activity of the protozoan community, e.g. on grazing rates and the generation time of heterotrophic nanoflagellates (Caron et al. 1986, Sherr et al. 1988), but also on the gross growth efficiency. Despite the low temperature, the ingestion and clearance rates of $<5 \mu \mathrm{m}$ heterotrophic nanoflagellates in Expt IV were high. The flagellate community probably consisted of species that were adapted to low temperature and fed effectively on bacteria, as also the volume-specific clearance was high.

Bacterial cell number and production declined with decreasing temperature (Expt III), but were recovered in Expt IV. However, the generation time of bacteria was not affected by changes in temperature. According to Scavia \& Laird (1987) bacterial growth rate is controlled by temperature only below $+10^{\circ} \mathrm{C}$, which agrees with this study.

\section{Grazing by microzooplankton}

Dominant ciliates in the enclosure had a minor role in the grazing of bacteria, except in Expt III. It is possible that ciliates could withstand fall in water temperature better than heterotrophic nanoflagellates, and still consume the whole bacterial production. The bacterial density in the experiments was high enough to sustain effective grazing by ciliates (Gast 1985, Albright et al. 1987, Sherr \& Sherr 1987), but the average size of bacteria was probably below threshold for ciliates (Fenchel 1980)

The proportion of microzooplankton that passed through $100 \mu \mathrm{m}$ sieve in this study was a rough estimate based on the previous studies from this area (Kivi unpubl.). Therefore the results give only an idea of the level of grazing on heterotrophic nanoflagellates. With the ingestion values obtained in Expts I and II, the $<100$ um protozoa used 48 and $108 \%$ of the flagellate standing stock in a day, respectively. The doubling times of flagellate population ( 1 and $0.7 \mathrm{~d}$ ) were short enough to keep the population growing. After the temperature decrease ciliate grazing on heterotrophic nanoflagellates was extremely weak.

\section{CONCLUSIONS}

In this study small heterotrophic nanoflagellates were the most important bacterial grazers, controlling bacterial numbers, production and population structure.
Temperature changes affected the activity of heterotrophic nanoflagellates and microprotozoa either directly or through changes in the bacterial population. Adaptation of the microbial community to low temperature took place in a few days. Also the inorganic nutrients added to the enclosure before the last grazing experiment could have enhanced the bacterial growth and production, and thereby the grazing intensity of protozoa.

The importance of heterotrophic nanoflagellates as the pathway of carbon to the next trophic level could only be suggested in the light of this study. It seemed, however, that a major part of the flagellate carbon was channelled to the grazing food web via ciliates, when favorable conditions for effective predation prevailed.

Acknowledgements. This study was conducted at the Tvärminne Zoological Station as a contribution to project PELAG. Thanks are addressed to Harri Kuosa for help with bacterial counts, inspiring discussions and comments on the manuscript, Esa Ranta for advice in statistical analysis, and Riitta Pajuniemi for the zooplankton data, and especially to Timo Tamminen for critical comments on the manuscript. Financial support by the Walter and Andree de Nottbeck Foundation is gratefully acknowledged

\section{LITERATURE CITED}

Albright, L. J., Sherr, E. B., Sherr, B. F., Fallon, R. D. (1987). Grazing of ciliated protozoa on free and particle-attached bacteri.a. Mar. Ecol. Prog. Ser. 38: 125-129

Andersen, O. K. Goldman, J. C., Caron, D. A., Dennett, M. R. (1986). Nutrient cycling in a microflagellate food chain: IIT. Phosphorus dynamics. Mar. Ecol. Prog. Ser 31: 47-55

Andersen, P. Fenchel, T (1985). Bacterivory by microheterotrophic flagellates in seawater samples. Limnol. Oceanogr. 30: 198-202

Andersson, A., Lee, C., Azam, F., Hagström, A. (1985). Release of aminoacids and inorganic nutrients by heterotrophic marine microflagellates. Mar Ecol. Prog. Ser. 23: 99-106

Andersson, A., Larsson, U., Hagström, \&. (1986). Size-selective grazing by a microflagellate on pelagic bacteria. Mar. Ecol. Prog. Ser 33: 51-57

Azam, F., Fenchel, T., Field, J. G., Gray, J. S., Meyer-Reil, L. A., Thingstad, F. (1983). The ecological role of watercolumn microbes in the sea. Mar. Ecol. Prog. Ser. 10: $257-263$

Bell, R. T., Ahlgren, G. M., Ahlgren, I. (1983). Estimating bacterioplankton production by measuring ${ }^{3} \mathrm{H}$-thymidine incorporation in a eutrophic Swedish lake. Appl environ Microbiol. 45: 1709-1721

Bergh, O,, Borsheim, K. Y., Bratbak, G., Heldal, M. (1989) High abundance of viruses found in aquatic environments. Nature, Lond. 340: 467-468

Bjornsen, P. K. (1986). Automatic determination of bactenoplankton biomass by image analysis. Appl. environ. Microbiol. 51. 1199-1204

Bjornsen, P. K., Riemann, B., Horsted, S J., Nielsen, T G., Pock-Sten, J. (1988). Trophic interactions between heterotrophic narloflagellates and bacterioplankton in manıulated seawater enclosures. Limnol. Oceanogr 33: 409-420

Bloem, J., Albert, C., Bär-Crilissen, M.-J. B., Berman, T., Cap- 
penberg, T E. (1989). Nutrient cycling through phytoplankton, bacteria and protozoa, in selectively filtered Lake Vechten water. J. Plankton Res. 11. 119-132

Bratbak, G. (1987). Carbon flow in an experimental microbial ecosystem. Mar Ecol. Prog. Ser. 36: 267-276

Borsheim, K. Y., Bratbak, G. (1987). Cell volume to cell carbon conversion factors for a bacterivorous Monas sp. enriched from seawater. Mar Ecol. Prog. Ser 36: 171-175

Campbell, L., Carpenter, E. J. (1986). Estimating the grazing pressure of heterotrophic nanoplankton on Synechococcus spp. using the sea water dilution and selective inhibitor techniques. Mar. Ecol. Prog. Ser. 33: 121-129

Caron, D. A. (1987). Grazing of attached bacteria by heterotrophic microflagellates. Microb. Ecol. 13: 203-218

Caron, D. A., Goldman, J. C., Dennett, M. R. (1986). Effect of temperature on growth, respiration and nutrient regeneration by an omnivorous microflagellate. Appl. environ. Microbiol. 52: 1340-1347

Coffin, R. B., Sharp, J. H. (1987). Microbial trophodynamics in the Delaware estuary. Mar Ecol. Prog. Ser. 41: 253-266

Coveney, M. F., Wetzel, R. G. (1988). Experimental evaluation of conversion factors for the $\left[{ }^{3} \mathrm{H}\right]$ thymidine incorporation assay of bacterial secondary production. Appl. environ. Microbiol. 54: 2018-2026

Cynar, F. J., Estep, K. W., Sieburth, J. McN. (1985). The detection and characterization of bacteria-sized protists in 'protist-free' filtrates and their potential impact on experimental marine ecology. Microb. Ecol. 11. 281-288

Fenchel, T. (1980). Suspension feeding in ciliated protozoa: functional response and particle size selection. Microb. Ecol. 6: 1-11

Fenchel, T. (1982a). Ecology of heterotrophic microflagellates. II. Bioenergetics and growth. Mar. Ecol. Prog. Ser. 8: 225-231

Fenchel. T (1982b). Ecology of heterotrophic microflagellates. IV Quantitative occurrence and importance as bacterial consumers. Mar. Ecol. Prog. Ser. 9: 35-42

Fuhrman, J. A., Azam, F. (1980). Bacterioplankton secondary production estimates for coastal waters of British Columbia, Antarctica, and California. Appl. environ. Microbiol. 39: 1085-1095

Fuhrman, J. A., Azam, F. (1982). Thymidine incorporation as a measure of heterotrophic bacterioplankton production in marine surface waters: evaluation and field results. Mar Biol. 66: 109-120

Fuhrman, J. A., Bell, T., M. (1985). Biological considerations in the measurement of dissolved free amino acids in seawater and implications for chemical and microbiological studies. Mar Ecol. Prog. Ser. 25: 13-21

Fuhrman, J. A., McManus, G. B. (1984). Do bacteria-sized eucaryotes consume significant bacterial production? Science 224: $1257-1260$

Gast, V (1985). Bacteria as a food source for microzooplankton in the Schlei Fjord and Baltic Sea with special reference to ciliates. Mar Ecol. Prog. Ser. 22: 107-120

Goldman, J. C., Caron, D. A., Andersen, O. K., Dennett, M. R. (1985). Nutrient cycling in a microflagellate food chain: I. Nitrogen dynamics. Mar Ecol. Prog. Ser. 24: 231-242

Haas, L. W. (1982). Improved epifluorescence microscopy for observing planktonic microorganisms. Ann. Inst. Oceanogr. Paris. 58: 261-266

Kirchman, D., Ducklow, H., Mitchell, R. (1982). Estimates of bacterial growth from changes in uptake rates and biomass. Appl environ. Microbiol 44: 1296-1307

Kivi, K. (1986). Annual succession of pelagic protozoans and rotifers in the Tvärminne Storfjärden, SW coast of Finland. Ophelia 4 (suppl.): 101-110
Krambeck, C. (1988). Control of bacterioplankton structures by grazing and nutrient supply during the decline of an algal bloom. Verh. Internat. Verein. Limnol. 23: 496-502

Kuosa, H. (1990). Picoplanktonic cyanobacteria in the northern Baltic Sea. the role in the phytoplankton community In: Barnes, M., Gibson, R. N. (eds.) Proc. 24th Eur Mar Biol. Symp. Aberdeen Univ. Press, p. 11-17

Kuosa, H., Kivi, K. (1989). Bacteria and heterotrophic flagel lates in the pelagic carbon cycle in the northern Baltic Sea. Mar. Ecol. Prog. Ser 53: 93-100

Kuosa, H., Marcussen, B. (1988). Grazing of bacteria and phytoplankton by heterotrophic nanoflagellates in a Baltic Sea sample. Hydrobiologia 161: 211-216

Kuparinen, J. (1987). Development of bacterioplankton during winter and early spring at the entrance to the Gulf of Finland. Baltic Sea. Verh. Int. Verein. Limnol. 23: 1869-1878

Kuuppo-Leinikki, P., Kuosa, H. (1990). Estimation of flagellate grazing on bacteria by size fractionation in the Northern Baltic Sea. Arch. Hydrobiol. Ergebn. Limnol 34: in press

May, K. R. (1965). A new graticule for particle counting and sizing. J. scient. Instrum. 42: 500-501

McManus, G. B., Fuhrman J. A. (1988). Clearance of bacteriasized particles by natural populations of nanoplankton in the Chesapeake Bay outflow plume. Mar. Ecol. Prog. Ser. 42: $199-206$

Moriarty, D. J. V., Pollard, P. (1982). Diel variation of bacterial productivity in seagrass (Zostera capricorni) beds measured by rate of thymidine incorporation into DNA. Mar Biol. 72: 165-173

Moriarty, D. J. V., Pollard, P., Hunt, W., Wassenburg, T (1985). Productivity of bacteria and microalgae and the effect of grazing by holothurians in sediments on a coral reef. Mar Biol. 85: 293-300

Nygaard, K., Børsheim, K. Y., Thingstad, T. F. (1988). Grazing rates on bacteria by marine heterotrophic microflagellates compared to uptake rates of bacterial-sized monodisperse fluorescent latex beads. Mar. Ecol. Prog Ser. 44: 159-165

Parslow, J. S., Doucette, G. J., Taylor, F. J. R., Harrison, P. J. (1986). Feeding by the zooflagellate Pseudobodo sp. on the picoplanktonic prasinomonad Micromonas pusilla. Mar Ecol. Prog. Ser. 29: 237-246

Porter, K. G., Pace, M. L., Battey, J. F. (1979). Ciliate protozoans as links in freshwater planktonic food chains. Nature, Lond. 277: 563-565

Rassoulzadegan, F., Sheldon, R. W. (1986). Predator-prey interactions of nanozooplankton and bacteria in an oligotrophic marine environment. Limnol. Oceanogr. 31. 1010-1021

Riemann, B. (1985). Potential importance of fish predation and zooplankton grazing on natural populations of freshwater bacteria. Appl. environ. Microbiol. 50: 187-193

Riemann, B., Bjørnsen, P. K., Newell, S., Fallon, R. (1987). Calculation of cell production of coastal marine bacteria based on measured incorporation of $\left[{ }^{3} \mathrm{H}\right]$ thymidine. Limnol. Oceanogr. 32: 471-476

Riemann, B., Nielsen, P., Jeppesen, M., Marcussen, B., Fuhrman, J. A. (1984). Diel changes in bacterial biomass and growth rates in coastal environments, determined by means of thymidine incorporation into DNA, frequency of dividing cells (FDC), and microautoradiography. Mar Ecol. Prog. Ser. 17: 227-235

Roman, M. R., Ducklow, H. W., Fuhrman, J. A., Garside, C., Glibert, P. M., Malone, T C., McManus, G. B. (1988). Production, consumption and nutrient cycling in a laboratory mesocosm. Mar Ecol. Prog. Ser. 42: 39-52

Sanders, R. W., Porter, K. G., Bennett, S. J., DeBiase, A. E. (1989). Seasonal patterns of bacterivory by flagellates, 
ciliates, rotifers, and cladocerans in a freshwater planktonic community. Limnol. Oceanogr. 34: 673-687

Scavia, D., Laird, G. A. (1987). Bacterioplankton in Lake Michigan: dynamics, controls, and significance to carbon flux. Limnol. Oceanogr. 32: 1017-1033

Sherr, E. B. (1988). Direct use of high molecular weight polysaccharide by heterotrophic flagellates. Nature, Lond. 335 : 348-351

Sherr, E. B., Sherr, B. F. (1987). High rates of consumption of bacteria by pelagic ciliates. Nature, Lond. 325: 710-711

Sherr, B. F., Sherr, E. B., Andrew, T. L., Fallon, R. D., Newell S. Y (1986). Trophic interactions between heterotrophic protozoa and bacterioplankton in estuarine water analyzed with selective metabolic inhibitors. Mar. Ecol. Prog. Ser. 32: 169-180

Sherr, B. F., Sherr, E. B., Berman, T. (1983). Grazing, growth, and ammonium excretion rates of a heterotrophic microflagellate fed with four species of bacteria. Appl. environ. Microbiol. 45: 1196-1201

Sherr, B. F., Sherr, E. B., Rassoulzadegan, F. (1988). Rates of digestion of bacteria by marine phagotrophic protozoa: temperature dependence. Appl. environ. Microbiol. 54: 1091-1095

Sibbald, M. J., Albright, L. J. (1988). Aggregated and free bacteria as food for heterotrophic microflagellates. Appl. environ. Microbiol. 54: 613-616

This article was submitted to the editor
Smits, J. D., Riemann, B. (1988). Calculation of cell production from $\left({ }^{3} \mathrm{H}\right)$ thymidine incorporation with freshwater bacteria. Appl. environ. Microbiol. 54: 2213--2219

Turley, C. M., Newell, R. C., Robins, D. B. (1986). Survival strategies of two small marine ciliates and their role in regulating bacterial community structure under experimental conditions. Mar. Ecol. Prog. Ser. 33: 59-70

Väätänen, P. (1981). Microbial ecology of brackish waters off the southern coast of Finland. Sci. Rep. No. 3, W. \& A. de Nottbeck Found. University of Helsinki, 1-22

Virtanen, A. (1985). Bacterial numbers, biomass, activity and production at a site in the Tvärminne area of the Gulf of Finland. Aqua Fennica 15: 143-160

Wikner, J. (1989). Predation on marine bacteria. Ph. D. thesis, Dept of Microbiology, University of Umeå

Wikner, J., Andersson, A., Normark, S., Hagström, Å. (1986). Use of genetically marked minicells as a probe in measurement of predation on bacteria in aquatic environments. Appl. environ. Microbiol. 52: 4-8

Wikner, J., Hagström, $\AA$. (1988). Evidence of a tightly coupled nanoplanktonic predator-prey link regulating the bacterivores in the marine environment. Mar. Ecol. Prog. Ser. 50: $137-145$

Wright, R. T., Coffin, R. B. (1984). Measuring microzooplankton grazing on planktonic marine bacteria by its impact on bacterial production. Microb. Ecol. 10: 137-149

Manuscript first received: August 17, 1989

Revised version accepted: March 7, 1990 